\title{
Dagmar Hofmann, Griechische Weltgeschichte auf Latein. Justins „Epitoma historiarum Pompei Trogi“" und die Geschichtskonzeption des Pompeius Trogus (Hermes Einzelschriften - 114), Franz Steiner Verlag, Stuttgart 2018, 456 pp. + 8 maps; ISBN 978-3-515-12143-9
}

An admirable trend in recent times has been the increased interest among scholars in Justin's (M. Junianus Justinus) work Epitome historiarum Philippicarum Pompeii Trogi, which, though well known to historians, ${ }^{1}$ for a long time did not enjoy any particular interest among philologists. The work is inextricably linked with the names of the two authors: Pompeius Trogus and Justin. The former lived at the time of emperor Augustus and wrote the 44-volume Historiae Philippicarum, which has not survived to our times. Yet we know its contents from the concise prologi, offering information about what the individual books covered, as well as the summary (epitome) made by Justin. This shows us that Pompeius Trogus presented the history of the great empires of Mesopotamia and Western Asia, Macedonia and the Hellenistic world. He completed his narrative in times contemporary to him. For a long time, the dominant belief was that the work of an epitomator, despite the various elements he added himself, scarcely deviated from the original. The results of the latest research on Justin's epitome, however, suggest that this view should be criticised, as should many other opinions on these two authors and their perception of history. It is purely coincidental that almost at the same time, two monographs - by Alice Borgna ${ }^{2}$ and Dagmar Hofmann - have been published, both presenting a new perspective on the works of both Pompeius Trogus and Justin.

Hofmann's book is based on her habilitation dissertation, submitted in 2016 at the University of Cologne. The author chose as her subject issues that had previously been discussed numerous times as well as others not previously analysed in detail. These include the question of the time when Justin's epitome was written, its relationship to

1 See Studi sull'epitome di Giustino, vol. 1: C. Bearzot, F. Landucci (eds.), Dagli Assiri a Filippo II di Macedonia, Milano 2014; vol. 2: C. Bearzot, F. Landucci (eds.), Da Alessandro Magno a Filippo V di Macedonia, Milano 2015; vol. 3: A. Galimberti, G. Zecchini (eds.), Il tardo ellenismo. I Parti e i Romani, Milano 2016.

2 Ripensare la Storia Universale. Giustino e l'epitome delle Storie Filippiche di Pompeo Trogo, Hildesheim-Zürich-New York 2018. See also ead., Da Pompeo a Giustino, in: Justino, Storie Filippiche. Florilegio da Pompeo Trogo, [Premessa di Giusto Traina. Saggio introduttivo, nuowa traduzione e note di Alice Borgna], Milano 2019, xxi-xlvii. 
Pompeius Trogus' work, Justin's way of presenting historical contents, and Pompeius Trogus' conception of history (cf. pp. 13-16). ${ }^{3}$

The first chapter ("Einleitung," pp. 13-22) contains a presentation of the research aims, a description of the methodology and a history of studies on Pompeius Trogus and Justin. In the subsequent chapters, the author analyses the specific issues concerning the two authors and the most important philological questions arising from the epitome. Key to explaining them is the time when they were written and the form of the work in all its aspects ("Der Epitomator und seine Vorlage," pp. 23-62). Scholars disagree on the dating of Justin's life and work. Some cite evidence suggesting that he lived in the 2nd century CE, while others opt for the third or even 4th century. According to Hofmann, numerous arguments - which she presents elsewhere in her book - suggest that the latter hypothesis is correct. She begins her study with an analysis of the earliest historical evidence on Justin's work, the character of the Praefatio that opens it (pp. 29-42), the time when Pompeius Trogus' prologi were written and their relations to Justin's epitome (pp. 42-62). Comparing the content of the prologi of the various volumes with content of the same books in the epitome leaves no doubt that Justin was faithfully following Pompeius Trogus' narrative. However, the style of his own narrative as well as the way he presents the events and figures described by Trogus is distinctly different.

The author discusses the literary and linguistic elements of the epitome, useful for dating its origin, in the chapter "Die Einordnung Justins in den sprachlichen und literarischen Kontext" (pp. 63-98). The results of her detailed philological analysis lead her to the conclusion that the language used by Justin is closest to that of the authors writing in the 4th century CE (pp. 72, 76-78). This in turn is a persuasive argument for dating his life to this time. ${ }^{4}$ The very nature of the work also supports this conclusion. An epitome was a literary genre that became very popular in this period (pp. 78-98). ${ }^{5}$ Justin's presentation of historical contents is demonstrated in the chapter "Geschichtsdarstellung bei Justin" (pp. 99-163). To illustrate it, the author makes use of two groups of examples: descriptions of rulers and exempla historiae cited, and mythological stories as well as those concerning the origin of various peoples (origines). Justin's narrative is not markedly different in terms of the facts presented from Pompeius Trogus' prologi, but on certain figures and events it has many added elements of a rhetorical, moralising and anecdotal nature, while others are mentioned almost in passing (pp. 99-121). The reason for this

3 "Das Ziel dieser Untersuchung besteht nicht nur darin, Justin in seiner Zeit und vor seinem historiographischen Hintergrund einzuordnen, sondern auch die Konsequenzen zu ziehen, die sich daraus für die Geschichtsdarstellung und die Geschichtskonzeption des Trogus ergeben . . . Das vordergründige Ziel der Studie ist . . . weder die historische Kommentierung einzelner Passagen der Epitome noch eine quellenkritische Bewertung, die über den Quellenwert einzelner Berichte und dessen Folgen für die historische Interpretation Auskunft gibt. Vielmehr konzentriert sich die vorliegende Untersuchung dezidiert auf die historiographische Einordnung der Epitome und des Originals sowie auf die Geschichtskonzepte, die in beiden Werken vermittelt werden" (p. 16).

4 It is worth adding that, despite the similarity to the language used by the Christian writers of the time, the epitome lacks any references to Christianity or to Justin's religious outlook. As a result, we can count him among the pagan intellectual elite of his time.

5 "Justins Epitome erfüllt, so läßt sich zusammenfassend feststellen, im Rahmen der Geschichtsschreibung im 4. Jh. gleich in mehrfacher Hinsicht Bedürfnisse . . . er wohl auch mit seiner inhaltlichen Auswahl, die seine eigene Geschichtsdarstellung ausmacht, den Geschmack seiner Zeit” (p. 98). 
treatment of the historical material was presumably a desire to satisfy the expectations of the Roman readers contemporary to Justin, since there was no reason to discuss issues outside of their interests at length. Moreover, in comparison to Pompeius Trogus, Justin pays considerably more attention to women, both mythological and historical (pp. 121136). However, they are used more for moralising purposes than for objective evaluation of their services. As for comparison of the mythological origines stories present in the epitome with the contents of Pompeius Trogus' prologi, not only are there far fewer, but those selected are only the ones that could be of interest to Justin's readers (pp. 137-163). Hofmann also notes that Justin writes relatively much about Armenia, which could result in the increased interest in a country which in the 4th century was at the centre of Roman policy as a result of the wars over it between Rome and the Persians. This fact, in addition to others she cited earlier, can be treated as one more argument in favour of dating the origin of the epitome to this period (cf. 159-161, 162).

The last of the major issues to which the author devotes a separate chapter is Pompeius Trogus' conception of history ("Die Geschichtskonzeption des Trogus," pp. 165222). She bases the reconstruction on the data contained in the prologi and in Justin's epitome. A knowledge of this is important, as in Augustus' time Pompeius Trogus was seen as a historian who was critical of Rome's past. This perception may have resulted from the fact that his work indeed contained scant references to the history of Rome. According to Hofmann, however, it was not any hostility to Rome on his part that was to blame for this marginal treatment - he himself was a Roman citizen — but rather the profile of the work. He was not a eulogist of Roman imperial policy criticising the one practised towards the Hellenistic world. To understand the nature of Trogus' work, it is important to know its original title. The one commonly used for it mainly derives from manuscript tradition, and can scarcely be deemed authentic (cf. pp. 174-181). Referring to the work as a general history is permissible, since at Trogus' time this was the accepted norm for describing the histories of other peoples. In contrast to Justin's narrative, Pompeius Trogus' account closely followed his chosen chronological and geographical order, reflecting Greek tradition. By using this, it was easier for him to present various periods of the history of the Hellenistic world. The chronological dividing lines he uses confirm this. These are marked by the date of the Battle of Corupedium (281 BCE), the destruction of Corinth (146 BCE), the end of Aristonicus' uprising against Rome and the death of Antiochus VII Sidetes (129 BCE), and Octavian's victory over Cleopatra (31 BCE). Each of these events closes an important chapter in Greek history (pp. 204211). Contrary to occasionally expressed views, one struggles to find in Trogus' work any promotion of the idea of translatio imperii, present in the writing (especially Jewish) of the Hellenistic period. There is much to suggest that his most important objective was to show the Romans a history about which they knew little — of the Greek world after the Macedonian conquest of Persia - and to make them realise that the Greeks and Macedonians also had an influence on the history of the world. The use of Latin to do this, as well as the very concept of the work, make Pompeius Trogus distinctive not only for his time, but also for the whole of Roman literature. ${ }^{6}$

6 "Das Alleinstellungsmerkmal des Trogus, das ihn von seine Vorgängern, die römische Geschichte auf griechisch schrieben, abhebt, ist aber, wie Justin in der Praefatio betont, zuallererst ein sprachliches: Daß Trogus griechische Weltgeschichte auf Latein abfaßte, war nicht nur in seiner Zeit eine Neuheit auf dem 
The author lists the most important findings from her research in a concise summary ("Weltgeschichte und Geschichtsabriss: Fazit," pp. 223-227).

A separate mention is due for the final, extensive part of the book, "Tabellen" (pp. 228-230). This comprises lists of the manuscripts containing the prologi and epitome (pp. 228-234), as well as analyses of their contents in table form (235-251), in addition to a summary of the references to Rome and the Romans included in them (pp. 366-372), a list of the linguistic parallels occurring in the epitome and other texts from the 1st century BCE until as late as the 6th century CE (pp. 252-285), a list of the people appearing in the epitome (pp. 286-319) with a separate list of women (pp. 330340), an inventory of exempla (pp. 320-329), the ethnographic excurses cited by Justin (pp. 341-365), and a list illustrating the geographical and chronological structure of Pompeius Trogus' work (pp. 373-380). The author's most important conclusions are based on the data contained in these tables.

Although the author, as a philologist, concentrates above all on the literary and philological aspects of Pompeius Trogus' prologi and Justin's epitome, her conclusions are also very significant for any researcher of these works. Griechische Weltgeschichte auf Latein is not an easy read, but it is certainly worth the effort to familiarise oneself with the author's findings. There is no doubt that by providing an overview of the two authors and their perspective on the past, illustrating the historical context in which they wrote and identifying the targets of their work, Hofmann provides a new insight into their works and a key enabling us to better understand their writings.

Edward Dąbrowa

iD http:/orcid.org/0000-0002-9324-9096

Jagiellonian University in Kraków

historiographischen Markt, sondern verlieh seinem Schaffen einen besonderen Status auch in interkultureller Hinsicht als Vermittler griechischer Heschichte in der römischen Welt” (p. 222). 